Refolding of Aggregation-Prone ScFv Antibody Fragments Assisted by Hydrophobically Modified Poly(sodium acrylate) Derivatives

\title{
Martin, Nicolas
}

2017-02

Martin , N , Costa , N , Wien , F , Winnik, F M , Ortega , C , Herbet , A , Boquet , D \& Tribet , C 2017 , ' Refolding of Aggregation-Prone ScFv Antibody Fragments Assisted by Hydrophobically Modified Poly(sodium acrylate) Derivatives ' , Macromolecular Bioscience , vol. 17 , no. 2 , 1600213 . https://doi.org/10.1002/mabi.201600213

http://hdl.handle.net/10138/308067

https://doi.org/10.1002/mabi.201600213

cc_by_nc

acceptedVersion

Downloaded from Helda, University of Helsinki institutional repository.

This is an electronic reprint of the original article.

This reprint may differ from the original in pagination and typographic detail.

Please cite the original version. 
Full Paper

\section{Refolding of Aggregation-prone ScFv Antibody Fragments Assisted by}

\section{Hydrophobically-Modified Poly(sodium acrylate) Derivatives.}

Nicolas Martin ${ }^{\dagger-2}$, Narciso Costa ${ }^{\ddagger}$, Frank Wien ${ }^{\S}$, Françoise M. Winnik ${ }^{\| 1-3}$, Céline Ortega ${ }^{*}$, Amaury Herbet ${ }^{\star}$, Didier Boquet ${ }^{\star}$, Christophe Tribet ${ }^{*},+1-2$

$\dagger^{1}$ Ecole normale supérieure, PSL Research University, UPMC Univ Paris 06, CNRS, Département de Chimie, PASTEUR, 24, rue Lhomond, 75005 Paris, France.

${ }^{2}$ Sorbonne Universités, UPMC Univ Paris 06, ENS, CNRS, PASTEUR, 75005 Paris, France.

\$CEA, iBiTecS, SPI, Laboratoire d’Ingénierie des Anticorps pour la Santé (LIAS), Bt. 136, CEA Saclay, F-91191 Gif sur Yvette, France

$\S$ Synchrotron Soleil, Saint-Aubin, F-91192 Gif-sur-Yvette, France

11 Department of Chemistry, Faculty of Pharmacy, Université de Montréal, CP 6128 Succursale Centre Ville, Montréal QC, H3C 3J7, Canada;

${ }^{12}$ World Premier Initiative (WPI) International Research Center Initiative, International Center for Materials Nanoarchitectonics (MANA) and National Institute for Materials Science (NIMS) 1-1Namiki, Tsukuba 305-0044 Japan

${ }^{13}$ Department of Chemistry and Faculty of Pharmacy, University of Helsinki, Helsinki FI 00014 Helsinki

keywords: Antibodies, Protein Folding, Chaperon-like Polymers, Synchrotron-radiation Circular Dichroism, Fluorescence Correlation Spectroscopy. 


\section{ABSTRACT}

$\mathrm{ScFv}$ antibody fragments are a promising alternatives to full-length antibodies for both therapeutic and diagnosis applications. They can be overexpressed in bacteria, which enables easy large scale production. Since scFv are artificial constructs, they are poorly soluble and prone to aggregation, which makes them difficult to manipulate and to refold. Here, we report stabilization and refolding of $\mathrm{scFv}$ fragments from urea-unfolded solutions based on the use of micromolar amounts of polymers playing the role of artificial chaperons. Using fluorescence correlation spectroscopy, we determined the size and aggregation number of complexes of scFv with unmodified or hydrophobically-modified poly(sodium acrylate). The evolution of the secondary structure along the refolding procedure, in the presence or absence of $0.4 \mathrm{M}$ L-arginine at scFv:polymer $<1: 5 \mathrm{wt} / \mathrm{wt}$, was determined by high-sensitivity synchrotron-radiation circular dichroism, SRCD. Measurements revealed that refolding in the presence of polymers yields native-like secondary structure, though a different folding pathway can be followed compared to refolding in the absence of polymer. This is the first report on the use of macromolecular additives to assist refolding of a multi-domain protein of therapeutic interest. 


\section{Introduction}

Therapeutic antibodies are among the fastest growing class of human drugs, and are now available in the form of various constructs, including antibody-drug conjugates, ${ }^{[1]} \mathrm{Fc}$-fusion proteins ${ }^{[2]}$ or antibody fragments. ${ }^{[3],[4]}$ Fragments lighter than the full-length antibody formats offer tremendous advantages for diagnostic and therapeutic applications. ${ }^{[4]}{ }_{,}^{[5]},{ }^{[6]}$ Due to their smaller size, fragments exhibit better tumor penetration ${ }^{[7]},{ }^{[8]}$ and faster clearance from healthy tissues, they can be fused to cytotoxic proteins ${ }^{[9]}$ and coupled to radiolabels ${ }^{[10]}$ or to cargo nanoparticles. ${ }^{[11]}$ Among fragments of antibodies, single-chain variable fragments (scFv) are the simplest constructs that retain the antigen-binding activity of the parent antibody. They are composed of two immunoglobulin (Ig) domains, the variable part of the light $\left(\mathrm{V}_{\mathrm{L}}\right)$ and heavy $\left(\mathrm{V}_{\mathrm{H}}\right)$ chains. These two domains are covalently linked via a flexible peptide linker to form a recombinant protein of molecular weight ca. $30 \mathrm{kDa}$.

Although $\mathrm{scFv}$ are promising therapeutic agents, they are artificially-designed proteins, which per-se creates drawbacks. Expression of recombinant proteins in prokaryotes often yields inclusion bodies, such that it becomes necessary to solubilize and refold the protein. ${ }^{[12],[13]}$ Single domain and stable proteins obtained from inclusion bodies can in principle be renatured by several means, including matrix assisted refolding procedures, ${ }^{[12]}$ or using osmolyte additives and chaperons. ${ }^{[14]}$ These generic tools provide however less benefits in the case of poorly stable, or non-natural constructs such as scFv. The multi-domain nature of $\mathrm{scFv}$ and the presence of several (four) disulfide bridges favor the formation of kineticallytrapped misfolded intermediates during refolding. Misfolded forms are generally not active, and may also be prone to irreversible aggregation. Thus renaturation requires cautious manipulation involving time-consuming, multiple steps with proper control of the redox and concentration conditions. ${ }^{[13],}{ }^{[15]}$ The irreversible aggregation often observed upon refolding of $\mathrm{scFv}$ is attributed to the poor stability of the $\mathrm{V}_{\mathrm{L}}-\mathrm{V}_{\mathrm{H}}$ interface. Transient dissociation of the two domains can result in the exposure to water of a hydrophobic surface. ${ }^{[16],{ }^{[17]}}$ The strong tendency of $\mathrm{scFv}$ towards aggregation is exacerbated by the exposure to water of hydrophobic residues that in "full" antibody structures are buried between the constant and variable domains. In natural sequences of $\mathrm{scFv}$ fragments, residues at this interface between variable and constant moieties are mainly hydrophobic, and therefore constitute a potentially aggregation-prone region. All these factors confer to most $\mathrm{scFv}$ an intrinsic proclivity for aggregation. Current approaches to enhance $\mathrm{scFv}$ solubility involve mutations of key residues, ${ }^{[18]}$ or covalent attachment of water-soluble macromolecules, such as $\mathrm{PEG}^{[19]},{ }^{[20]},{ }^{[21]}$, 
which may result in loss of the scFv bioactivity. Formulation-based strategies have also been applied with some success: chemical additives conventionally added during renaturation of $\mathrm{scFv}$ fragments or in storage conditions include urea, osmolytes, notably L-arginine ${ }^{[22]},{ }^{[23]}$ or detergents. ${ }^{[24]}$ These additives circumvent the instability issues of $\mathrm{scFv}$ but they are efficient only at high (molar) concentrations, which prevents in vivo administration and may bias in vitro activity assays.

We recently reported the use of low concentrations of poly(acrylic acid) (PAA) and its amphiphilic derivatives to slow down the thermal aggregation of full antibodies (immunoglobulins $\mathrm{G}, \mathrm{IgG}$ ) and to renature soluble enzymes. ${ }^{[25]}{ }_{\left[{ }_{\mu}\right.}^{[26]},{ }^{[27]}$ In both cases, the protein colloidal stability was markedly enhanced by addition of polymer in a $1: 1 \mathrm{w} / \mathrm{w}$ protein/polymer ratio, a value much lower than the usual concentrations of "stabilizing" excipients, such as osmolytes or detergents. The effect of PAA at low polymer:protein ratios, in particular with antibodies, has been ascribed to the formation of transient coulomb associations with positively charged patches on the protein surface. ${ }_{\mu}^{[25]}$ The surface charge of $\mathrm{scFv}$ fragments was estimated to be globally positive in the experimental buffer used here at pH 8 with a calculated isoelectric point of 9.0 (see also SI scheme S1 showing positive patches). We thus explored here the use of $\mu \mathrm{M}$ concentrations of anionic polyacrylate derivatives in the context of the renaturation of urea-dissolved cationic scFv's and their protection against aggregation during their refolding. The polymers employed, shown in Scheme 1, were derived from poly(acrylates) parent chains by hydrophobic modification (parent PAA of molar mass either $5 \mathrm{~kg} \cdot \mathrm{mol}^{-1}$, PAA5, or $150 \mathrm{~kg} \cdot \mathrm{mol}^{-1}$, PAA150). Both the short and the long copolymers of sodium acrylate and $N$ - $n$-octadecylacrylamide contained 3 mol \% $N$ - $n$-octadecylacrylamide (PAAx-3C18, with $\mathrm{x}=5$ or 150 ). A terpolymer of sodium acrylate, $N$ - $n$-octylacrylamide $(25 \mathrm{~mol} \%)$ and $N$-isopropylacrylamide $(40 \mathrm{~mol} \%)$ derived from short PAA5 (PAA5-25C8-40C3) was used also, as representative of the class of Amphipols, that are used to stabilize membrane proteins. ${ }^{[28]}$ We characterized the size of protein and protein:polymer soluble complexes, and the degree of protein folding. Aggregation and/or complexation of scFv's with polymers during refolding from ureadenatured solutions was monitored by fluorescence correlation spectroscopy (FCS) using fluorescently-labeled scFv. Secondary structure changes during refolding were followed by synchrotron radiation circular dichroism (SCRCD) studies of mixed polymer:scFv solutions (typically $1: 1 \mathrm{w} / \mathrm{w}$ ).

We demonstrate that the polymers selected preserve $\mathrm{scFv}$ in monomeric or oligomeric forms during refolding. Although they affect the folding pathway, they lead to the recovery

\begin{tabular}{|l|}
\hline Field Code Changed \\
\hline Field Code Changed \\
\hline Field Code Changed \\
\hline Field Code Changed \\
\hline Field Code Changed \\
\hline Formatted: English (United States) \\
\hline Formatted: English (United States) \\
\hline Field Code Changed \\
\hline Formatted: English (United States) \\
\hline
\end{tabular}


of native-like secondary conformation from unfolded $\mathrm{scFv}$ in a denaturant-free aqueous environment. 


\section{Experimental Section}

\subsection{Materials}

Water was deionized with a MilliQ Millipore purification system. Urea, guanidine hydrochloride $(\mathrm{Gu}-\mathrm{HCl})$, L-arginine, reduced or oxidized glutathione, and 2-amino-2(hydroxymethyl)-1,3-propanediol (Tris) were purchased from Sigma-Aldrich and used without further purification. The poly(acrylic acid) (PAA) samples (nominal average molecular weight $\left(\mathrm{M}_{\mathrm{w}}\right)$ 5,000 g.mol ${ }^{-1}$ (PAA5) or 150,000 g.mol ${ }^{-1}$ (PAA150)) were purchased from Sigma-Aldrich. The molar mass $\left(\mathrm{M}_{\mathrm{w}}\right)$ and polydispersity index $(\mathrm{PI})$ of the polymers in the sodium acrylate form were $\mathrm{M}_{\mathrm{w}}=6,500 \mathrm{~g} \cdot \mathrm{mol}^{-1}$, PI $\sim 2(\mathrm{PAA} 5)$ and $\mathrm{M}_{\mathrm{w}} \sim 130,000 \mathrm{~g} \cdot \mathrm{mol}^{-1}$, PI $~ 4$ (PAA150), as determined by GPC using a Waters system equipped with Waters 2414 Refractive Index and Waters 2487 UV-Visible Absorbance detectors, and 4 Waters Styragel HR 5E columns eluted with $0.5 \mathrm{M}$ LiNO calibrated poly(ethyleneoxide) standards ${ }^{[29]}{ }^{[30]}$. Random copolymers of acrylic acid and $N$ - $n$-octadecylacrylamide (3-4 mol \%, PAA5-3C18 and PAA150-3C18) were prepared by coupling $N$-n-octadecylamine to carbodiimideactivated PAA, following a procedure described previously ${ }^{[30]}$. PAA5-25C8-40C3 $\left(\mathrm{M}_{\mathrm{W}} 9,000\right.$ $-10,000$ g.mol ${ }^{-1}$ ) was purchased from ANATRACE (Amphipol A8-35, Affymetrix).

\subsection{ScFv expression and purification}

Three scFv fragments were used: scFv Sha31 ( Mw 29,000 g. $\mathrm{mol}^{-1}$ ), which binds the naturally occurring prion protein, scFv $12 \mathrm{G} 4\left(\mathrm{Mw} 29,000 \mathrm{~g} \cdot \mathrm{mol}^{-1}\right)$, which is directed against the human anti-Mullerian hormone type II receptor ${ }^{[31]}$; and scFv Rendomab B1 (Mw 30,400 g. $\left.\mathrm{mol}^{-1}\right)$, which targets the human endothelin B receptor. ${ }^{[32]}$ All fragment sequences were expressed following the same procedure: E. Coli BL21 (DE3) transformed with the prokaryotic expression vector SPI 4 encoding the $\mathrm{scFv}$ fragment of interest ${ }^{[33]}$ were grown in shaking culture $\left(220 \mathrm{rpm}, 37^{\circ} \mathrm{C}\right)$ in LB broth supplemented with $50 \mu \mathrm{g} \cdot \mathrm{mL}^{-1}$ kanamycin to an OD of 0.6 at $600 \mathrm{~nm}$. Protein expression was induced by addition of $1 \mathrm{mM}$ isopropyl $\beta$-D1-thiogalactopyranoside (IPTG) and incubation for $3 \mathrm{~h}\left(220 \mathrm{rpm}, 30^{\circ} \mathrm{C}\right)$. Induced cells were harvested by centrifugation at $4,000 \mathrm{~g}$ for $10 \mathrm{~min}$ at $4{ }^{\circ} \mathrm{C}$ and resuspended in Tris- $\mathrm{HCl}$ buffer $(0.1 \mathrm{M}, \mathrm{pH} 8)$ containing protease inhibitors $\left(\mathrm{Pefabloc}^{(\mathrm{R})} \mathrm{SC}\right)$. The solution was sonicated and centrifuged at $14,000 \mathrm{~g}$ for $10 \mathrm{~min}$ at $4^{\circ} \mathrm{C}$. The supernatant was discarded and the pellet was solubilized in buffer A $(6 \mathrm{M}$ guanidine- $\mathrm{HCl}$ or $8 \mathrm{M}$ urea, $5 \mathrm{mM}$ Tris(2carboxyethyl)phosphine, $20 \mathrm{mM}$ imidazole, $0.1 \mathrm{M}$ Tris- $\mathrm{HCl} \mathrm{pH} \mathrm{8),} \mathrm{and} \mathrm{incubated} \mathrm{for} 1 \mathrm{~h}$ $\left(230 \mathrm{rpm}, 37^{\circ} \mathrm{C}\right)$. The lysate was sonicated $(1 \mathrm{~min}, 16 \mathrm{~W})$ and cleared by centrifugation at 
$14,000 \mathrm{~g}$ for $30 \mathrm{~min}$ at $4^{\circ} \mathrm{C}$, and $0.45 \mu \mathrm{m}$ filtration of the supernatant. The scFv fragment was purified by Immobilized Metal Affinity Chromatography (in a $1 \mathrm{~mL}$ HisTrap HP column (GE Healthcare), Biologic LP apparatus, loading and washing with buffer A at $0.5 \mathrm{~mL} \cdot \mathrm{min}^{-1}$, elution in buffer B: $6 \mathrm{M}$ guanidine- $\mathrm{HCl}$ or $8 \mathrm{M}$ urea, $5 \mathrm{mM}$ Tris(2-carboxyethyl)phosphine, $200 \mathrm{mM}$ imidazole, $0.1 \mathrm{M}$ Tris- $\mathrm{HCl} \mathrm{pH} 8$ at $0.5 \mathrm{~mL} \cdot \mathrm{min}^{-1}$ ). Pooled elution fractions were fractionated by size exclusion chromatography in buffer B without imidazole. Fractions of the monomeric form of $\mathrm{scFv}$ were pooled and the final concentration (as measured by bicinchoninic acid, BCA, assay) was adjusted to $15 \mu \mathrm{M}$.

\subsection{Preparation of fluorescently-labeled scFv}

Purified scFv ( $5 \mathrm{mg}$ ) was incubated with His-Select HF batch resin ( $3 \mathrm{~mL}$, Sigma) during $15 \mathrm{~min}$ at room temperature, then the mixture was subjected to centrifugation at 3,000 $\mathrm{g}$ for 8 $\min$ at $4{ }^{\circ} \mathrm{C}$. The recovered resin was washed twice with $10 \mathrm{~mL}$ of denaturing buffer $(6 \mathrm{M}$ guanidine- $\mathrm{HCl}, 5 \mathrm{mM}$ Tris(2-carboxyethyl)phosphine, $20 \mathrm{mM}$ imidazole, $0.1 \mathrm{M}$ Tris- $\mathrm{HCl} \mathrm{pH}$ 8) and twice with $10 \mathrm{~mL}$ of borate buffer $\mathrm{pH}$ 8.5. A $15 \mathrm{mM}$ solution of FITC (Fluorescein isothiocyanate, Thermo Fisher Scientific) $(3 \mathrm{~mL})$ in borate buffer $\mathrm{pH} 8.5$ was added to the resin. The mixture was incubated for $2.5 \mathrm{~h}$ at room temperature. The resin was washed five times with $10 \mathrm{~mL}$ of borate buffer and twice with the denaturing buffer. The labeled scFv was eluted with the elution buffer (6 M guanidine- $\mathrm{HCl}, 5 \mathrm{mM}$ Tris(2-carboxyethyl)phosphine, $200 \mathrm{mM}$ imidazole, $0.1 \mathrm{M}$ Tris- $\mathrm{HCl} \mathrm{pH} 8)$. The dye:scFv molar ratio $(\sim 1)$ was determined by UV-vis spectroscopy $(495 \mathrm{~nm})$. Low degree of modification with fluorescein is generally believed to have only a mild impact on scFv properties. ${ }^{[34]}{ }^{[35]}$

\section{4. scFv fragments refolding protocol in the absence or presence of polymers}

The reference renaturation protocol was adapted from procedures described previously ${ }_{\mu}^{[36],[31]}$. The concentration of $\mathrm{scFv}$ was adjusted to $10 \mu \mathrm{M}$ in $6 \mathrm{M}$ guanidine- $\mathrm{HCl}$ $(\mathrm{Gu}-\mathrm{HCl})$ or $8 \mathrm{M}$ urea, $0.1 \mathrm{M}$ Tris- $\mathrm{HCl} \mathrm{pH} 8$ buffer. $\mathrm{Gu}-\mathrm{HCl}$ or urea were removed by dialysis with stepwise reduction of the denaturant concentration to $4 \mathrm{M}$ (for $48 \mathrm{~h}$ ), $2 \mathrm{M}, 1 \mathrm{M}$, $0.5 \mathrm{M}$ and 0 (for $12-24 \mathrm{~h}$ at each concentration), using Slide-A-Lyzer MINI dialysis devices (MWCO 3,500 Da, ThermoScientific). In samples containing no polymer, 0.4 M L-arginine was added to the buffers throughout the stepwise dialysis to prevent protein aggregation. The oxidized and reduced forms of glutathione $(0.75 \mathrm{mM}$ and $7.5 \mathrm{mM}$, respectively) were added in the final steps of the dialysis (against $1 \mathrm{M}$ and $0.5 \mathrm{M}$ denaturant). 
When renaturation was performed without L-arginine, polymers were added to the buffer at the first step of refolding procedure (i.e. in the $6 \mathrm{M}$ guanidine- $\mathrm{HCl}$ or $8 \mathrm{M}$ urea, $0.1 \mathrm{M}$ Tris$\mathrm{HCl} \mathrm{pH} 8$ buffer), at a weight ratio $\leq 5: 1$ compared to protein. L-arginine was not added during the stepwise dialysis in the presence of polymers (see Scheme 2).

\subsection{Fluorescence correlation spectroscopy}

FCS measurements were performed on a home-built two-photon excitation system equipped with a mode-locked Ti:Sapphire laser (Mira900, Coherent, Auburn, CA) pumped by a solid-state laser at $532 \mathrm{~nm}$ (Verdi, Coherent). The laser beam $(780 \mathrm{~nm}, \sim 100$-fs pulse width) was focused into the sample using a $60 \times$ water immersion microscope objective $(1.2$ NA, UPlanApo, Olympus). The power was kept below $10 \mathrm{~mW}$ by means of neutral filters. The fluorescence signal was collected through the same objective lens, filtered and reflected by dichroic filters to select fluorescein fluorescence $(580 \pm 30 \mathrm{~nm})$. The collected light was then separated by a beam splitter and focused on two APDs (SPCM-AQR-14, PerkinElmer, Vaudreuil, Canada). At the concentrations used in this study, the typical signal from APD was about 3-10 kHz. The signal outputs were acquired by a digital autocorrelator module (ALV-6000, ALV-GmbH, Langen, Germany) which computed the cross-correlation function of the fluorescence fluctuations, $g(t)$. The data were analyzed using the MEMFCS algorithm described elsewhere ${ }^{[37]}$. The diffusion time measured at the maximum of the distribution obtained with the MEMFCS algorithm was related to the diffusion coefficient by: $\tau_{D}=$ $\omega_{x y}^{2} / 8 D$. The hydrodynamic radius was then calculated via the Stokes-Einstein equation. The excitation area $\omega_{x y}^{2}$ was calibrated by using the diffusion coefficient of fluorescein in water:denaturant mixtures as a standard.

\subsection{Synchrotron-radiation circular dichroism}

SRCD measurements were carried out on the DISCO beamline of the SOLEIL synchrotron facility in Saclay (France). Measurements were performed at $25^{\circ} \mathrm{C}$ on $\sim 5 \mu \mathrm{L}$ of $5 \mathrm{mg} \cdot \mathrm{mL}^{-1}$ $\mathrm{scFv}$ (with or without polymer) solutions placed between two calcium fluoride windows separated by an optical pathlength of $0.012 \mathrm{~cm}$ (urea- and L-arginine-containing samples) or $0.055 \mathrm{~cm}$ (samples devoid of urea or L-arginine). Three successive acquisitions were averaged for each sample (integration time: $1200 \mathrm{~ms}$, wavelength step: $1 \mathrm{~nm})$. (1R)-(-)-10camphorsulfonic acid (CSA) was used as a calibration standard. The mean molar residue ellipticity was calculated from the $\theta$ machine units (in mdeg) via the relationship: 


$$
\left.[\theta]=\frac{0.1 \times \theta \times M_{R}}{p \times c} \quad \text { (Eq. } 1\right)
$$

where $M_{R}$ is the mean molecular weight of a residue in the considered fragment, $p$ is the cuvette pathlength (in $\mathrm{cm}$ ) and $c$ is the concentration (in $\mathrm{mg}^{\mathrm{mL}} \mathrm{mL}^{-1}$ ) of the fragment.

The renaturation protocol was adapted to meet SRCD requirements. Samples of $5 \mathrm{mg} \cdot \mathrm{mL}^{-1}$ (ca. $160 \mu \mathrm{M}$ ) scFv fragment in 4-10 M urea, $0.01 \mathrm{M}$ Tris-HCl $\mathrm{pH} 8$ buffers were prepared by dilution of a scFv stock solution (10 mg. $\mathrm{ml}^{-1}$ in $10 \mathrm{M}$ urea). Samples were supplemented or not with an aliquot of $10 \mathrm{mg} \cdot \mathrm{mL}^{-1}$ polymer (either in $10 \mathrm{M}$ urea, or in $0.01 \mathrm{M}$ Tris- $\mathrm{HCl} \mathrm{pH} 8$ ), to reach a final polymer concentration of $5 \mathrm{mg} \cdot \mathrm{mL}^{-1}(1: 1 \mathrm{w} / \mathrm{w}$ compared to the protein), and let to equilibrate for $24 \mathrm{~h}$ before SRCD measurements. Further decrease of urea concentration was performed by stepwise dialysis successively against 2, 1, 0.5 and $0 \mathrm{M}$ urea, $0.01 \mathrm{M}$ Tris$\mathrm{HCl} \mathrm{pH} \mathrm{8,} \mathrm{with} \mathrm{addition} \mathrm{of} \mathrm{reduced} \mathrm{and} \mathrm{oxidized} \mathrm{glutathione} \mathrm{(7.5} \mathrm{and} 0.75 \mathrm{mM}$, respectively) in buffers below $2 \mathrm{M}$ urea. L-arginine $(0.4 \mathrm{M})$ was added in the absence of polymers.

\subsection{Flow cytometry}

Specific binding of entire or refolded $\mathrm{scFv}$ rendomab B1, in the presence or absence of polymers, was evaluated by flow cytometry using the FACS-Calibur (BD Bioscience, Franklin Lakes, USA) flow cytometer. Measurements were performed on stably transfected CHO cell lines expressing ETBR (CHO-ETBR). ETBR-free CHO-WT (wild-type) were used as a reference for non-specific interaction. In brief, cell suspensions were pre-incubated with $\mathrm{scFv}$ or mAb solutions, washed, and then exposed to a secondary, fluorescently-labeled antibody in order to reveal the binding. We determined the mean fluorescence intensity (MFI) as the average fluorescence of 30000 cells.

In more details, $95 \%$ confluent cells in $75-\mathrm{cm}_{\Perp}^{2}$ flasks were washed with phosphate buffer saline (D-PBS, Invitrogen) and collected after incubation at $37^{\circ} \mathrm{C}$ for $15 \mathrm{~min}$ in $10 \mathrm{~mL}$ of versene buffer (D-PBS/8 mM EDTA). Cell suspensions were loaded in Falcon tubes (300,000 cells/tube), sedimented by mild centrifugation to remove the excess buffer, and then incubated for $2 \mathrm{~h}$ at $4^{\circ} \mathrm{C}$ with $300 \mu \mathrm{L}$ of RendomAb B1 (resp. RendomAb scFv) at a concentration of $100 \mathrm{nM}$, (resp. $1 \mu \mathrm{M}$ ) in ice-cold D-PBS/1\% BSA/5\% NGS buffer. The suspension was then washed twice in $150 \mu \mathrm{L}$ D-PBS/1\% BSA $/ 5 \%$ normal goat serum (NGS, invitrogen) buffer, prior to incubation for $1 \mathrm{~h}$ at $4^{\circ} \mathrm{C}$ in $150 \mu \mathrm{L}$ of $\mathrm{F}\left(\mathrm{ab}^{\prime}\right) 2-\mathrm{Goat}$ anti-Mouse $\operatorname{IgG}(\mathrm{H}+\mathrm{L})$ Alexa Fluor ${ }^{\circledR} 488$ conjugate (ThermoFisher) (resp. for scFv incubated cells, AntiHA-FITC antibody, Sigma). After two washing steps (mild centrifugation, resuspension in $100 \mu \mathrm{L}$ of D-PBS/1\% BSA), fluorescence was determined by FACS. 
To check hETBR expression at cell surfaces, $1 \mu \mathrm{M}$ fluorescein-labeled endothelin (ET-1 FAM, Phoenix Pharmaceuticals), a peptide sepcifically recognized by the receptor, was used as the positive control.

\section{Results and Discussion}

\subsection{Size of scFv during refolding}

In a first set of experiments we monitored the refolding of FITC-labeled scFv Sha 31 from the denatured state in either urea or guanidinium hydrochloride using FCS, a highly sensitive technique that reports the hydrodynamic radius and aggregation number of nanometer-sized fluorescent objects in the $\mathrm{nM}$ to $\mu \mathrm{M}$ concentration range. Non-fluorescent objects are not detected by FCS and do not interfere in the measurement, allowing in situ size measurements of the fluorescent species. Since the polymers used were not fluorescently labeled, FCS analyses of polymer/FITC-scFv Sha 31 mixtures provided information on the size of all FITC-scFv-containing species in solution: $\mathrm{scFv}$ monomers, $\mathrm{scFv}$ aggregates, and $\mathrm{scFv}$ :polymers complexes. Polymers and polymer aggregates in solution escaped detection (see Experimental Section, and ESI for details).

Experiments were performed starting from denatured FITC-scFv Sha31 either in $10 \mathrm{M}$ urea or in $6 \mathrm{M}$ guanidine hydrochloride $(\mathrm{Gu}-\mathrm{HCl})$, in the absence of polymer. The denaturant concentration was selected based on previous studies showing that $\mathrm{Gu}-\mathrm{HCl}$ solubilizes and unfolds proteins more efficiently than urea. The refolding procedure consisted in decreasing the denaturant concentration by a set of successive dialyses against more and more diluted denaturant solutions (Scheme 2). scFv solutions in either $\mathrm{Gu}-\mathrm{HCl}$ or urea were diluted via dialyses to a denaturant concentration of $4 \mathrm{M}$. Further dilutions were conducted either in the presence of L-arginine (0.4 M; denoted + L-arginine) or without L-arginine (- L-arginine) (see Experimental Section). The evolution of the average hydrodynamic radius $\mathrm{R}_{\mathrm{h}}$ of FITC$\mathrm{scFv}$-containing species as a function of the decreasing denaturant concentration is presented in Figure 1. Note that in this figure the denaturant concentration increases from left to right along the $\mathrm{x}$-axis, while the refolding experiments were conducted from the highest concentration to 0 , i.e. from right to left. The $R_{h}$ of denatured FITC-scFv was $\leq 4 \mathrm{~nm}$. It remained constant upon denaturant dilution down to $4 \mathrm{M}$. At this point, the evolution of the FITC-scFv size varied depending on the composition of the denaturant solution. In L- 
arginine-containing denaturant solutions, the $\mathrm{R}_{\mathrm{h}}$ of FITC-scFv remained $\sim 4 \mathrm{~nm}$ or decreased slightly as the denaturant solution was diluted down to 0 (red curves in Figure 1). This result confirms the stabilizing effect of L-arginine reported previously. ${ }^{[24]}{ }^{[22]},{ }^{[36]}$ In solutions of $\mathrm{Gu}-\mathrm{HCl}$ supplemented with L-arginine, the drop of $\mathrm{R}_{\mathrm{h}}$ between from $\sim 3.4 \mathrm{~nm}$ to $2.1 \mathrm{~nm}$ upon $\mathrm{Gu}-\mathrm{HCl}$ dilution from $2 \mathrm{M}$ to $1 \mathrm{M}$ is attributed to a conformational transition of FITC-scFv from a coil into a compact globule. This transition was not observed in FITC-scFv solutions in urea $+\mathrm{L}$-arginine (Figure $1 \mathrm{~b}$, red curve).

In the absence of L-arginine, a decrease of the denaturant concentration induced protein aggregation: in the case of $\mathrm{Gu}-\mathrm{HCl}$, aggregation took place abruptly as $[\mathrm{Gu}-\mathrm{HCl}]<1.5 \mathrm{M}$. In urea, aggregation as detected by the increase of FITC-scFv size started for [urea] $<4 \mathrm{M}$, but it was more gradual than in the case of $\mathrm{Gu}-\mathrm{HCl}$. Eventually, while approaching $0 \mathrm{M}$ denaturant concentration, the FCS signal displayed strong bursts of intensity (Figure S1 in ESI), indicative of the presence of large fluorescent aggregates, which rendered size measurements unreliable. In summary, addition of $0.4 \mathrm{M}$ L-arginine efficiently prevents aggregation of FITC-scFv during refolding in either urea- or $\mathrm{Gu}-\mathrm{HCl}$-denatured solutions. However removal of L-arginine from the solution of FITC-scFv obtained at the end of Larginine-supplemented refolding procedures triggers immediate aggregation of FITC-scFv (not shown), confirming the poor colloidal stability of FITC-scFv alone, even in the form of folded globules. A similar precipitation was observed upon removal of L-arginine after refolding of unlabeled $\mathrm{scFv}$, suggesting that the lack of stability of $\mathrm{scFv}$ was not due to the covalent attachment of fluorescein groups (which are water soluble at $\mathrm{pH} 8$ ). Although a slight difference in stability of FITC-scFv (1 fluorescein per scFv molecule) compared to unlabelled scFv could be expected, the collapse and aggregation conditions of FITC-scFv, or as described below their complexation with polymers, are indicative here of the main qualitative trends likely to occur also with unlabelled scFv.

\subsection{Polymer-induced protection against scFv aggregation during refolding}

We prepared polymer:FITC-scFv $(5: 1 \mathrm{w} / \mathrm{w})$ solutions in denaturant ([urea] $=10 \mathrm{M}$ or $[\mathrm{Gu}-$ $\mathrm{HCl}]=6 \mathrm{M}$ ) without L-arginine (see Experimental Section) to test the ability of PAA derivatives to prevent FITC-scFv aggregation during refolding. The solutions were subjected to the same refolding protocol as in the case of FITC-scFv alone. FCS measurements of mixed polymer/FITC-scFv solutions report the size of FITC-scFv/polymer complexes, if formed, in addition to the size of FITC-scFv. Since the polymer $\mathrm{R}_{h}$ values, recorded previously by dynamic light scattering, are on the order of $15 \mathrm{~nm}$ to $20 \mathrm{~nm}$, FITC- 
$\mathrm{ScFv}$ /polymer complexes are expected to be significantly larger than FITC-scFv. ${ }^{[25]}$ Plots of the changes of $\mathrm{R}_{\mathrm{h}}$ and aggregation numbers of FITC-scFv in the presence of polymers are presented in Figure 2 as a function of denaturant concentration. The $R_{h}$ values recorded for solutions of FITC-scFv in [Gu-HCl] $>2 \mathrm{M}$ and [urea] $>3 \mathrm{M}$ in the presence of PAA150 and PAA5-25C8-40C3 were identical to those of FITC-scFv alone suggesting that FITC-scFv does not interact with these polymers in these denaturant concentration conditions. In urea solutions of FITC-scFv containing PAA150-3C18, the $\mathrm{R}_{\mathrm{h}}$ values recorded over the $10 \mathrm{M}$ to 1 $\mathrm{M}$ urea concentration range were $\sim 14 \mathrm{~nm}$, implying that this polymer $\left(\mathrm{R}_{\mathrm{h}} 16 \pm 3 \mathrm{~nm}\right)^{[25]}$ interacts with unfolded FITC-scFv in urea.

In solutions of $[\mathrm{Gu}-\mathrm{HCl}]<1.5-2 \mathrm{M}$, the polymers failed to protect FITC-scFv against aggregation as detected by a sharp increase of $R_{h}$ (Figure $2 a$ ). In contrast, in urea solutions the polymers prevented massive aggregation of FITC-ScFv. For example, in mixed FITC$\mathrm{scFv} / \mathrm{PAA} 150$ solutions $\mathrm{R}_{\mathrm{h}}$ increased gradually for [urea] $<2 \mathrm{M}$ up to a value of $\sim 50 \mathrm{~nm}$ suggesting the formation of FITC-scFv:PAA150 complexes. The complexes remained dispersed in solution, as [urea] was decreased to $0 \mathrm{M}$. A similar FITC-scFv stabilization was observed in urea solutions containing PAA150-3C18 where species of $R_{h}$ ca. $27 \mathrm{~nm}$ formed down to $0 \mathrm{M}$ urea. The size of the species corresponds to the expected size of soluble polymer/FITC-scFv complexes containing not more than a few polymer chains. Association between urea-unfolded FITC-scFv and the low mass polymer PAA5-25C8-40C3 cannot be detected by FCS based on the $R_{h}$ value of fluorescent object detected, since the $R_{h}$ value of the polymer is too small $(\sim 5 \mathrm{~nm})$. Nonetheless, the fact that the $\mathrm{R}_{\mathrm{h}}$ value measured down to $0 \mathrm{M}$ urea stays below $11 \mathrm{~nm}$ indicates that stabilization was achieved in this solution as well (Figure S1 in ESI). Importantly, in samples that do not suffer from massive FITC-scFv aggregation (no fluorescence burst in FCS signal), calculated (average) aggregation numbers of $\mathrm{scFv}$ were $<2$, and often $\sim 1$ indicating that protein monomers predominate in solution (Figure 2d, FCS analysis based on the fluorescence intensity, see ESI). Thus values of radii $>$ $4 \mathrm{~nm}$, possibly as high as $50 \mathrm{~nm}$ recorded at low denaturant concentrations correspond essentially to monomers (possibly small oligomers when $\mathrm{N}_{\mathrm{agg}} \sim 1.5$ ) of FITC-scFv surrounded by larger, non-fluorescent, polymer chains. Similar protective effects were obtained for solutions containing less polymer (FITC-scFv:polymer weight ratio as low as 1:1; not shown).

\subsection{Folding transition monitored by SRCD}


Each step of the refolding procedure was monitored by high-sensitivity SRCD in order to unveil the impact of the presence of polymers on the evolution of the $\mathrm{scFv}$ (no FITC) secondary structures and folding transition. We discuss first the changes in SRCD signals for $\mathrm{scFv}$ alone, and next in the presence of polymers, in 4-10 M urea. The SRCD spectrum of scFv Rendomab B1 in $10 \mathrm{M}$ to $8 \mathrm{M}$ urea in the absence of polymer shows the characteristic features of unfolded polypeptide chains (single deep minimum at $203 \mathrm{~nm}$ ) (Figure 3a). As [urea] $<8 \mathrm{M}$ the mean residual ellipticity at $203 \mathrm{~nm}$ increases while its value at $218 \mathrm{~nm}$ decreases, which is attributed to the (partial) folding of the fragment. The shape of the SRCD spectrum of scFv solutions with [urea] $<5 \mathrm{M}$ shows features of a $\beta$-sheet-enriched structure, with a minimum at $\sim 215 \mathrm{~nm}$, typical of antibody-like structures. ${ }^{[38]}$ Since the SRCD spectra of $\mathrm{scFv}$ display no isodichroic point, the folding of $\mathrm{scFv}$ cannot be described by a two-state equilibrium, as reported previously by Plückthun et al. ${ }^{[16]}$ who demonstrated that the folding transition of $\mathrm{scFv}$ fragments is cooperative, broad and involves several intermediate states, betraying the multi-domain nature of the $\mathrm{scFv}$ fragment. The plot of the changes with urea concentration of the mean molar residue ellipticity at $218 \mathrm{~nm}$, a wavelength characteristic of the $\beta$-sheet-rich structure, (Figure $4 \mathrm{a}$, black curve) presents a sharp transition for [urea] 7 M. Figure $4 \mathrm{~b}$ presents the urea concentration dependence of the $[\theta]_{203} \mathrm{~nm}$ value, characteristic of the unfolded state. In the absence of polymer, upon decreasing [urea] from 8 $\mathrm{M}$ to $4 \mathrm{M},[\theta]_{203} \mathrm{~nm}$ increases gradually up to zero, indicating that unstructured elements disappear gradually.

In solutions of scFv containing PAA150-3C18 or PAA5-25C8-40C3 (Figure 4 and spectra in Figure $\mathrm{S} 2$ in ESI), the transition from unfolded scFv to the $\beta$-sheet-rich conformation took place gradually over a wider urea concentration range than in the case of $s c F v$ alone, suggesting that the two amphiphilic polymers decrease the scFv folding cooperativity. The SRCD signal (Figure 3c-d, Figure 4) presents no significant variation at $218 \mathrm{~nm}$ below $7 \mathrm{M}$ urea and essentially increases during dilution of urea from $10 \mathrm{M}$ to $7-8 \mathrm{M}$. Thus the disappearance of disordered regions is shifted toward higher urea concentrations as compared to $\mathrm{scFv}$ without polymer, implying that the presence of these polymers favors the $\mathrm{scFv}$ folding. In contrast, the SRCD spectra of ScFv:PAA150 mixed solutions were nearly identical to those of solutions of $\mathrm{scFv}$ alone (Figure $3 \mathrm{~b}$ and Figure 4). Altogether, analysis of the [urea] dependence of the SRCD spectra recorded for $\mathrm{ScFv}$ in the presence of either PAA150-3C18 or PAA5-25C8-40C3 indicates that the folding transition of scFv is affected significantly by these two polymers and proceeds through different intermediates, compared to the case of solution of scFV alone or in the presence of PAA150. 


\subsection{Native-like secondary structure recovery}

SRCD measurements were performed with solutions of scFv Rendomab B1 of [urea] $<4$ $\mathrm{M}$, to assess if it is possible to obtain from them the native-like secondary structure with either $0.4 \mathrm{M} \mathrm{L}$-arginine or polymer. SRCD spectra recorded for $\mathrm{scFv}$ solutions containing polymers were indicative of the absence, or weak ( experimental uncertainties), variations in secondary structure with decreasing [urea] from $4 \mathrm{M}$ down to $0 \mathrm{M}$ (Figure 5 and S3 in ESI). Strikingly, SRCD spectra of scFv solutions with polymers exhibited a marked minimum at $\sim 215 \mathrm{~nm}$ and a maximum at $190 \mathrm{~nm}$, indicative of a predominant $\beta$-sheet structure, and characteristic of an antibody-like folded conformation. ${ }^{[38]}$ The SRCD spectra of urea-free solutions containing polymers are nearly identical, independently of the polymer structure (Figure 5). Although the polymers play an active role in the refolding of $\mathrm{scFv}$, their exact composition does not seem to be of importance to the final secondary structure reached in absence of urea. In the presence of L-arginine (no polymer), SRCD spectra recorded for $\lambda>$ $200 \mathrm{~nm}$ were noisy, hampering a detailed data analysis (Figure 5 and Figure S2 in ESI). For $\lambda$ $<200 \mathrm{~nm}$, measurements of SRCD was not possible due to high UV-absorption of Larginine ([L-arginine $]=400 \mathrm{mM}$; [scFv amino acids $] \sim 45 \mathrm{mM}$ at $5 \mathrm{mg} \cdot \mathrm{mL}^{-1}$ ), or due to aggregation in the absence of L-arginine. Measurements at wavelengths $>200 \mathrm{~nm}$ suggest nevertheless that SRCD spectra evolved toward shapes that were qualitatively distinguishable from the one obtained in the presence of polymers (minimum of SRCD signal shifted to lower wavelength in Figure 5 and Figure S2 in ESI).

The SRCD spectra obtained after complete removal of urea were deconvoluted into linear combinations of contributions from elemental secondary structures ( $\alpha$-helices, $\beta$-sheets, others) using the BeStSel method, optimized for both far-UV SRCD and $\beta$-sheet-rich proteins and taking into account contributions of complex $\beta$-structures, such as twisted $\beta$-sheets ${ }^{[39]}$, Table 1). The native-like proportion (in mol\% of residues) of each secondary structure was computed from the crystal structure of scFv Rendomab B1 (denoted as "Model" in Table 1, Dr. E Stura and Dr. Nicolas Prudhomme, personal communication). Values obtained with Rendomab B1 solutions matched with the native-like \% within experimental errors (Table 1), independently of the polymer structure. This conclusion also applied to $\mathrm{scFv} 12 \mathrm{G} 4$ refolded in the presence of polymers PAA150-3C18, PAA 5-25C8-40C3, or L-arginine (Table 1). In contrast, the secondary structure estimated for scFv Rendomab B1 refolded with L-arginine differed markedly from the native structure. In particular, it was estimated that $\mathrm{scFv}$ 
contained higher amount of $\alpha$-helix (> 15\% instead of $\sim 2-3 \%$, N.B. differences in $\% \beta$-sheet may be due to the poorly defined signal obtained at low wavelengths in the presence of Larginine). Note that upon removal of arginine, no spectra could be recorded due to the massive aggregation of polymer-free scFv solutions. Only polymer-containing samples were transparent by eye and could be characterized by SRCD in buffer without arginine. In addition, as polymer-supplemented solutions were transparent all along the refolding procedure, the average molar rotations presented in Figures $3-5$ were calculated assuming no loss of $\mathrm{scFv}$, i.e. full solubility up to the end of refolding.

The BeStSel analysis predicts reliably the topology of the protein fold in terms of the CATH classification, a hierarchical protein structure classification method. ${ }^{[40]}$ This "fold recognition" feature lists the relative frequencies (in \%) of protein classes, architectures, and topologies that are the closest to those of the protein studied (see ${ }^{[39]}$ for details). With scFv fragments refolded in the presence of polymers, this data treatment systematically led to folded conformations with more than $52 \%$ (and up to 100\%) of "mainly $\beta$ " class, more than $44 \%$ (and up to 83\%) of "sandwich-like" architecture, and more than 35\% (and up to $70 \%$ ) of "immunoglobulin-like" topology. The other listed classes, architectures, and topologies had relative frequencies comprised between 0.3 and $15 \%$, i.e. values well below the predominant mainly $\beta$, sandwich-like, immunoglobulin-like fold. In summary, refolding of scFv fragments in the presence of polymers resulted in a majority of native-like secondary structures as determined from SRCD results.

\subsection{Functional binding assays.}

To assess the preservation of specific recognition in the presence of polymer, we have performed fluorescence flow cytometry experiments. Rendomab B1 mAb is directed against ETBR, a membrane protein. ${ }^{[32]}$ Its binding on cells expressing ETBR is usually revealed by a fluorescent secondary antibody recognizing the constant domain of mAb. In the case of Rendomab B1 scFv, as the constant domain is lacking, we relied on its $\mathrm{N}$-terminal peptide Tag HA to reveal the binding by formation of a sandwich complex with an anti-HA antibody. The smallest polymer PAA5-25C8-40C3 was used in the assays, essentially to characterize the smallest $\mathrm{scFv}$ :polymer complexes, as the most promising system for applications (with longer polymer chains, the higher radius of complexes -see chapter 3.2- may diminish the practical advantages of using small scFv compared to mAbs). Results are presented in Figure 
6, as the mean fluorescence per cell difference, MFI, of CHO-ETBR (specific + non-specific binding) compared with CHO-WT (only non specific binding). With the full $\mathrm{mAb}$ (Rendomab B1), the presence of polymer PAA5-25C8-40C3 has no clear effect on binding as compared to assay conducted in the absence of polymer indicating that the polymer do not interfere with specific binding. Similarly, MFI measured with urea-refolded $\mathrm{scFv}$ in the presence or absence of polymer did not differ by more than uncertainties. It is important to note that the MFI values obtained for the mAb and the scFv cannot be compared due to i) the fact that revelation antibodies are different and ii) $\mathrm{mAb}$ is bivalent while $\mathrm{scFv}$ is a monovalent binder. Interestingly, the values obtained for the Rendomab B1 scFv in presence or absence of polymer are in the same MFI range as the positive control, i.e the binding of ET1-FAM. Finally, it is concluded that the polymer doesn't interfere with the rendomab B1 scFv binding on ETBR.

\subsection{Possible origins of the polymer-induced protection}

Non covalent protein/polymer interactions are known to protect various proteins, mainly small globular single-domain enzymes, against stress-induced (e.g. $\mathrm{pH}$, temperature) denaturation or against aggregation during refolding. The protection and/or association was attributed primarily to hydrophobic binding of the polymers with unfolded proteins or folding intermediates and, less frequently, to Coulomb interactions. ${ }^{[27]}\left[{ }^{[41]},[42],{ }^{[43]},{ }^{[44]}\right.$. The protection of partly-folded proteins was ascribed to the increased solubility of the protein:polymer complexes, for instance in the cases of carbonic anhydrase ${ }^{[27]}$, lysozyme ${ }^{[45]}$ alphachymotrypsin ${ }^{[41]}$ and alpha-amylase ${ }^{[42]}$ ), to the hydrophobically-mediated interfacial immobilization of proteins on polymer nanoparticles ${ }^{[46],[47]}$ or on polymer micelles ${ }^{[48]}{ }^{[49]}$, or to confinement in nanogels (of pullulan ${ }^{[50]}$ or in PNIPAM ${ }^{[51]}$ ). In each case, it was concluded that sequestration of the protein resulted in their stabilization against aggregation by immobilizing aggregation-prone species. Release of native proteins was achieved by changing the environmental conditions, such as the ionic strength, the $\mathrm{pH}$, or by addition of a competitive molecule that weakened the interaction of the protein with its artificial chaperon. Our recent studies indicate that hydrophobically-modified linear poly(sodium acrylate) derivatives can form dynamic complexes with bovine carbonic anhydrase that reach significant protein renaturation yields without additional weakening step. ${ }^{[27]}$

To our knowledge, there are no examples so far of polymer-assisted renaturation of $\mathrm{scFv}$ fragments or other therapeutic multi-domain proteins. We show here that PAA derivatives prevent $\mathrm{scFv}$ aggregation during its refolding from a urea-denatured soluble state, but these 
polymers are ineffective in the refolding of $\mathrm{scFv}$ in the high ionic strength conditions imposed by $\mathrm{Gu}-\mathrm{HCl}$ which screens ionic interactions. This observation, together with prevention of the massive aggregation of scFv:polymer complexes in urea solutions, but not in $\mathrm{Gu}-\mathrm{HCl}$, suggests that electrostatic interactions between the polymers and $\mathrm{scFv}$ are necessary to ensure the success of the refolding process. The fact that FITC-scFv:PAA1503C18 complexes form in urea, but not in $\mathrm{Gu}-\mathrm{HCl}$ salt, suggests that hydrophobic interactions enhance the efficiency of the polymer protective effect, but only in concert with attractive Coulomb interactions.

Finally, SRCD measurements showed that amphiphilic polymers decreased the cooperativity of folding and, at high [urea], induced a transition from the unfolded conformation to a partially folded structure, indicating that amphiphilic polymers stabilized intermediate folding states. This result is somewhat surprising. Usually, complexation of globular proteins with amphiphilic polymers or surfactants that render the proteins more

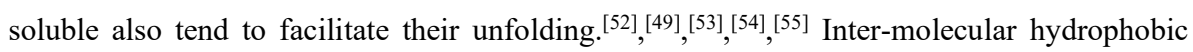
association competes with intra-protein interactions and should destabilize folded states. Our observation that hydrophobically-modified polymers favor more structured scFv suggests a preferential association of the polymer with folded or partly-folded conformers that exhibit more hydrophobic surfaces than the completely unfolded states. Unlike most natural globular proteins that bury their hydrophobic residues in the core of their globular structure, scFv are non-natural fragments displaying hydrophobic areas exposed to water (and buried in the full IgG antibodies). The multi-domain nature of $\mathrm{scFv}$ should also not be overlooked: early hydrophobic association with polymers may for instance favor partial folding of each domain upon stabilization of the hydrophobic inter-domain contact area.

\section{Conclusion}

In this work, we provide the first evidence that hydrophobically-modified PAA derivatives, and PAA, are efficient aggregation suppressors during the refolding of $\mathrm{scFv}$ antibody fragments. Complexes between $\mathrm{scFv}$ and PAA derivatives are formed at low, ca. 10-50 micromolar, concentrations of polymers and proteins in urea-containing solutions. Their typical hydrodynamic radius is of the order of the radius of the polymer chains (5 to $50 \mathrm{~nm}$ depending on the polymer used here). Absence of stabilization in the presence of ionic denaturant $(\mathrm{Gu}-\mathrm{HCl})$ suggested that Coulomb binding between $\mathrm{scFv}$ and poly(acrylates) 
significantly contributed to complexation. Refolding in the presence of complexes (urea) yields native-like secondary structures which differs from the non-native structure detected in L-arginine-stabilized (aggregate-free) solutions. $\mathrm{scFv}$ are two-domain proteins that typically show high cooperativity of refolding between their domains. The help provided by polymers in facilitating the correct refolding, while preserving the monomer form of the protein, suggests a very efficient chaperon-like efficiency. Of practical importance, replacing high and possibly toxic concentrations of L-arginine with micromolar, non-toxic ${ }^{[56]}$ amount of polymers (typically $1: 1$ to $1: 5 \mathrm{w} / \mathrm{w}$ protein/polymer ratio) should open routes to use soluble and stable polymer:scFv complexes in diagnostic applications based on specific targeting of cells, possibly in vivo. From the fundamental viewpoint, the results of this study suggest that hydrophobic associations with polymers favor the folding of artificial scFv constructs, which contrasts with the usual hydrophobic destabilization of the monodomain natural enzymes reported previously. The stabilization of folded conformations through hydrophobic interactions suggests that sub-optimal conformational stability of artificial, engineered proteins may be counter-balanced by non-covalent association with amphiphilic polymer additives.

Acknowledgments: This work was supported by the French National Research Agency (program Blanc International, grant ANR 2010-INT 1501, and program Investissement d'Avenir ANR-11-LABX-0011-01. 
Table 1. BeStSel secondary structure content determination of scFv Rendomab B1 and scFv 12G4, at $25^{\circ} \mathrm{C}$ in $10 \mathrm{mM}$ Tris- $\mathrm{HCl} \mathrm{pH} 8$, after refolding from $10 \mathrm{M}$ urea aqueous solutions, with or without polymers $(1: 1 \mathrm{w} / \mathrm{w}$ scFv:polymer ratio), or with $0.4 \mathrm{M} \mathrm{L}$-arginine. $\mathrm{scFv}$ concentration was ca. 5 mg.mL $L^{-1}$.

\begin{tabular}{|c|c|c|c|c|c|c|}
\hline \multirow[b]{2}{*}{ Condition } & \multicolumn{3}{|c|}{ scFv Rendomab B1 } & \multicolumn{3}{|c|}{ scFv 12G4 } \\
\hline & $\alpha$-helices & $\begin{array}{c}\text { anti-parallel } \\
\beta \text {-sheets }\end{array}$ & others $^{\mathrm{c}}$ & $\alpha$-helices & $\begin{array}{c}\text { anti-parallel } \\
\beta \text {-sheets }\end{array}$ & others ${ }^{\mathrm{c}}$ \\
\hline Model $^{\mathrm{a}}$ & 2.5 & 40 & 57.5 & na & na & na \\
\hline L-arginine ${ }^{b}$ & 16 & 10.5 & 73.5 & 3.5 & 40 & 56.5 \\
\hline PAA5 & 2 & 39.5 & 58.5 & nd & nd & nd \\
\hline PAA150 & 3.5 & 37 & 59.5 & 6 & 31 & 63 \\
\hline PAA5-3C18 & 2.5 & 38 & 59.5 & nd & nd & nd \\
\hline PAA150-3C18 & 3 & 35 & 62 & 3 & 37 & 60 \\
\hline PAA5-25C $8-40 C 3$ & 3.5 & 36 & 60.5 & 4.5 & 39.5 & 56 \\
\hline
\end{tabular}

a determination of the secondary structure content of scFv Rendomab B1 from its 3D crystallographic structure.

${ }^{\mathrm{b}}$ refolding without polymers but with $0.4 \mathrm{M}$ L-arginine

${ }^{\mathrm{c}}$ turns and unstructured elements

nd: not determined ; na: not applicable 
PAAx

$(x=5$ or 150$)$

$+\mathrm{CH}_{2}-\mathrm{CH}+-$
PAA $x-3 \mathrm{C} 18$

$(x=5$ or 150$)$

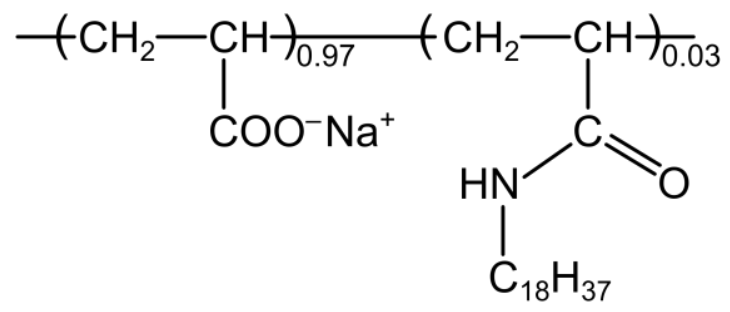

PAA5-25C8-40C3

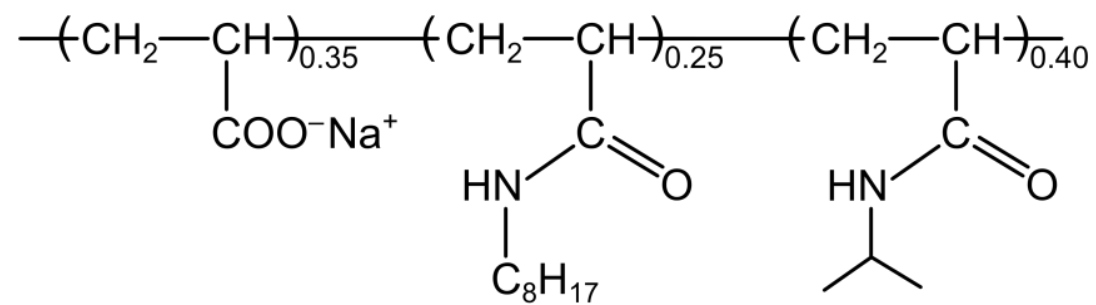

Scheme 1. Chemical structure of the polymers investigated. 


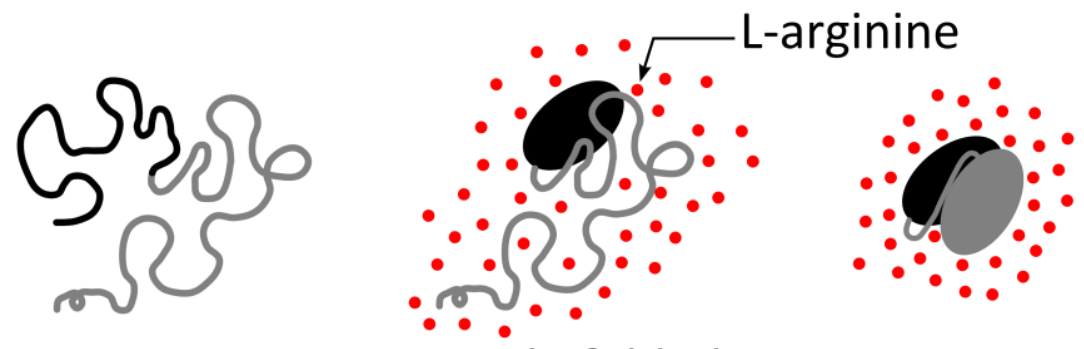

unfolded states $\rightarrow$ partly-folded $\rightarrow$ native state
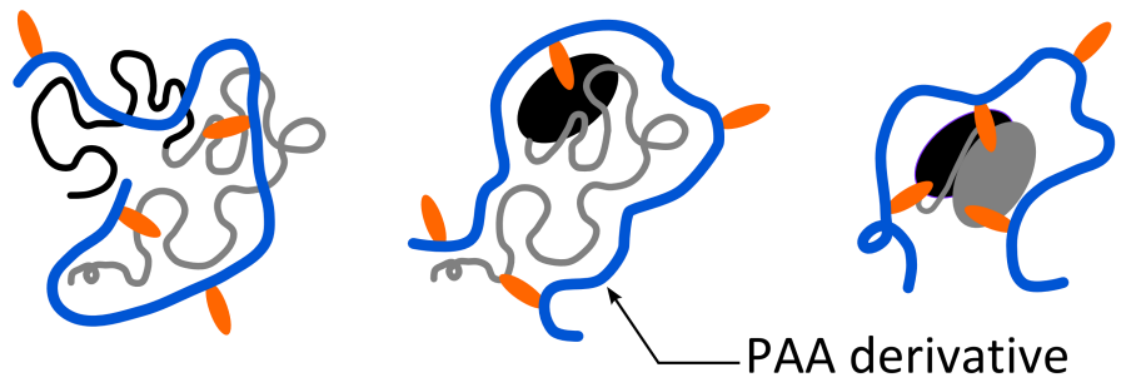

PAA derivative

\section{$>8 \mathrm{M}$ urea or} $6 \mathrm{M} \mathrm{Gu}-\mathrm{HCl}$

NO denaturant

Scheme 2. Schematic illustration of the refolding protocol of $\mathrm{scFv}$ fragments in the absence (top) or presence (bottom) of PAA derivatives. In the absence of polymer, L-arginine is added from $4 \mathrm{M}$ denaturant down to $0 \mathrm{M}$ denaturant to prevent $\mathrm{scFv}$ aggregation. 


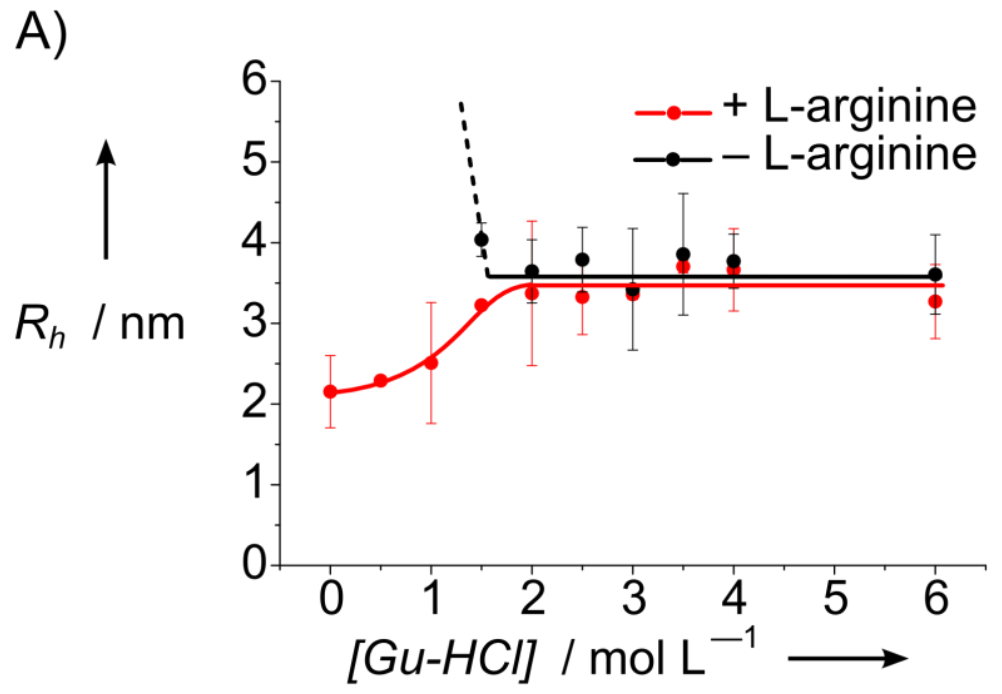

B)

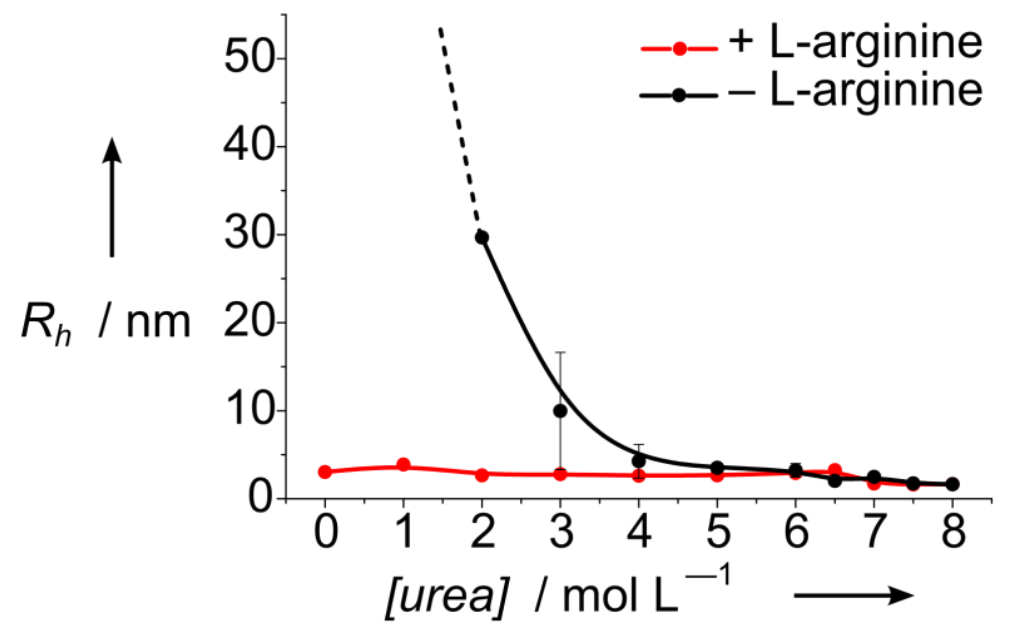

Figure 1. Variation upon dialysis at decreasing $\mathrm{Gu}-\mathrm{HCl}$ (A) or urea (B) concentrations of the hydrodynamic radius $R_{h}$ of FITC-scFv Sha31 measured by FCS. L-arginine $(0.4 \mathrm{M})$ was added or not as quoted from $4 \mathrm{M}$ denaturant down to $0 \mathrm{M}$ denaturant. $[\mathrm{scFv}]=0.1 \mathrm{mg} \cdot \mathrm{mL}^{-1}$. 
A)

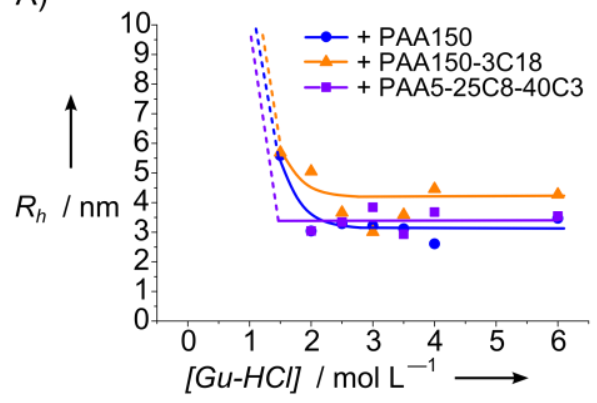

C)

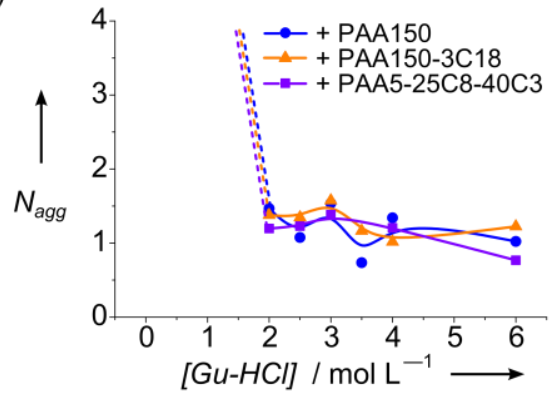

B)

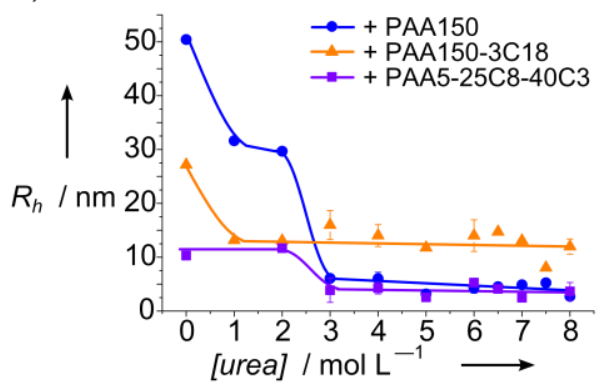

D)

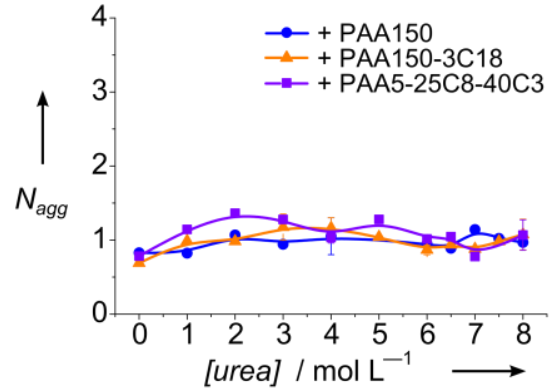

Figure 2. Variation of the hydrodynamic radius $\mathrm{R}_{\mathrm{h}}$ and aggregation number, as measured by FCS, of FITC-scFv Sha31 dialyzed against decreasing $\mathrm{Gu}-\mathrm{HCl}(\mathrm{A}, \mathrm{C})$ or urea (B, D) concentrations (refolding procedure) in the presence of polymers (no L-arginine). $[\mathrm{scFv}]=$ $0.1 \mathrm{mg} \cdot \mathrm{mL}^{-1}$, [polymer] $=0.5 \mathrm{mg} \cdot \mathrm{mL}^{-1}$. Lines are guide to the eye. 

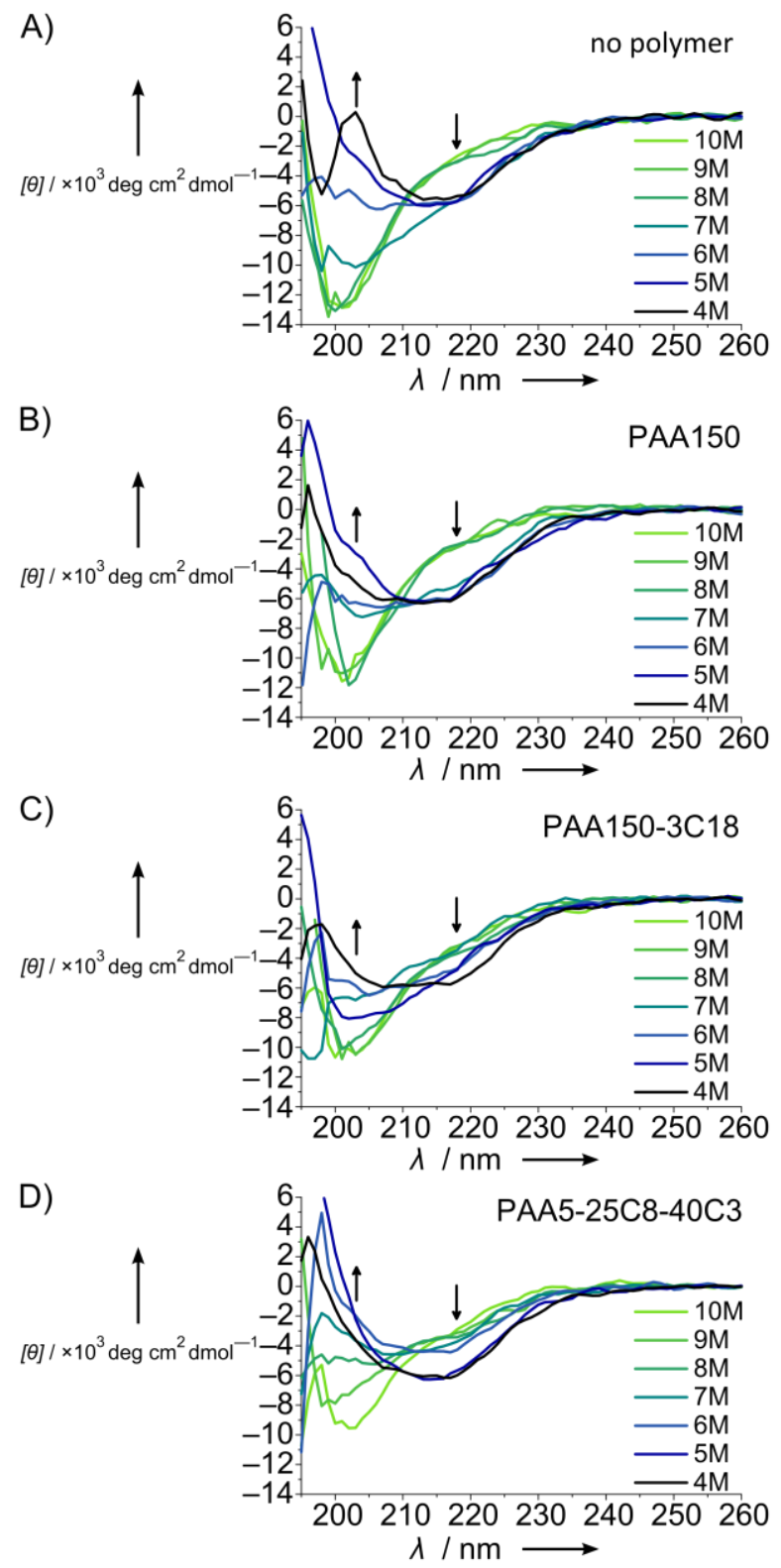

Figure 3. $\mathrm{SRCD}$ spectra of $\mathrm{scFv}$ Rendomab $\mathrm{B} 1$ in the 4-10 $\mathrm{M}$ urea range, $10 \mathrm{mM}$ Tris- $\mathrm{HCl}$ $\mathrm{pH} 8$ at $25^{\circ} \mathrm{C}$, (A) in the absence of polymer, or (B) in scFv:PAA150 1:1 wt/wt, (C) in scFv:PAA150-3C18 1:1 wt/wt, (D) in scFv:PAA5-25C8-40C3 1:1 wt/wt mixed solutions. $[\mathrm{scFv}]=5 \mathrm{mg} \cdot \mathrm{mL}^{-1}$. 
A)

$[\theta] / \times 10^{3} \mathrm{deg} \mathrm{cm}^{2} \mathrm{dmol}^{-1}-4$.

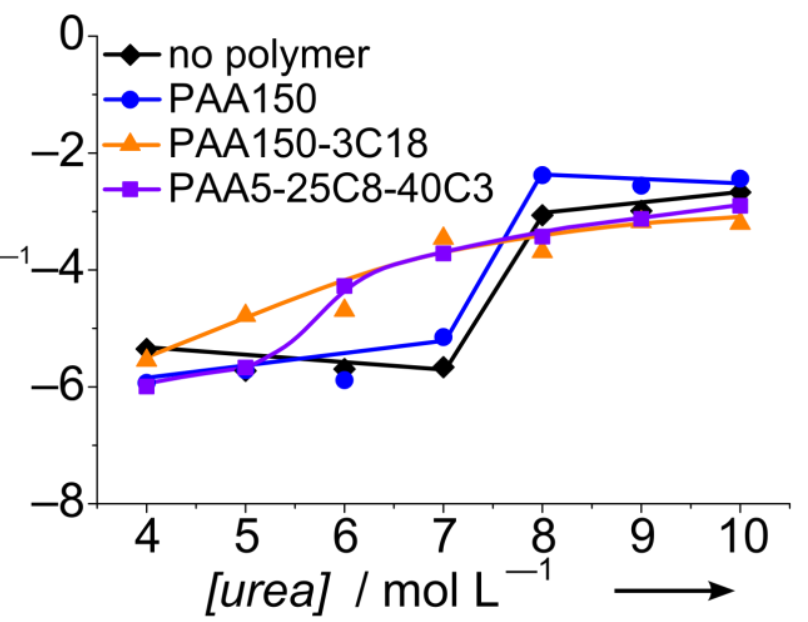

B)

$[\theta] / \times 10^{3} \mathrm{deg} \mathrm{cm}^{2} \mathrm{dmol}^{-1}-6$

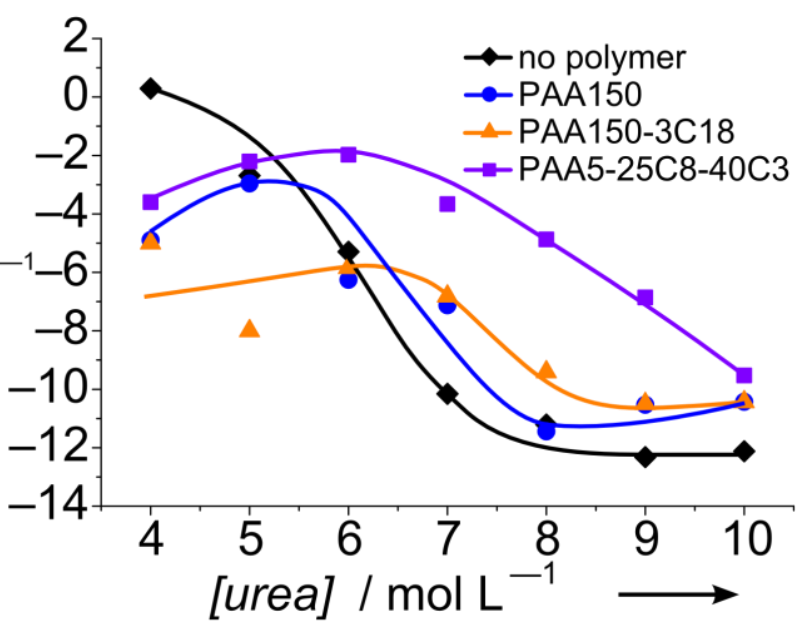

Figure 4. SRCD-monitored folding transition of $\mathrm{scFv}$ Rendomab $\mathrm{B} 1$ in the presence of polymers: evolution of the mean molar ellipticity [ $\theta]$ at $218 \mathrm{~nm}(\mathrm{~A})$ and $203 \mathrm{~nm}$ (B) in the 4$10 \mathrm{M}$ urea range. Lines are guide to the eye. 


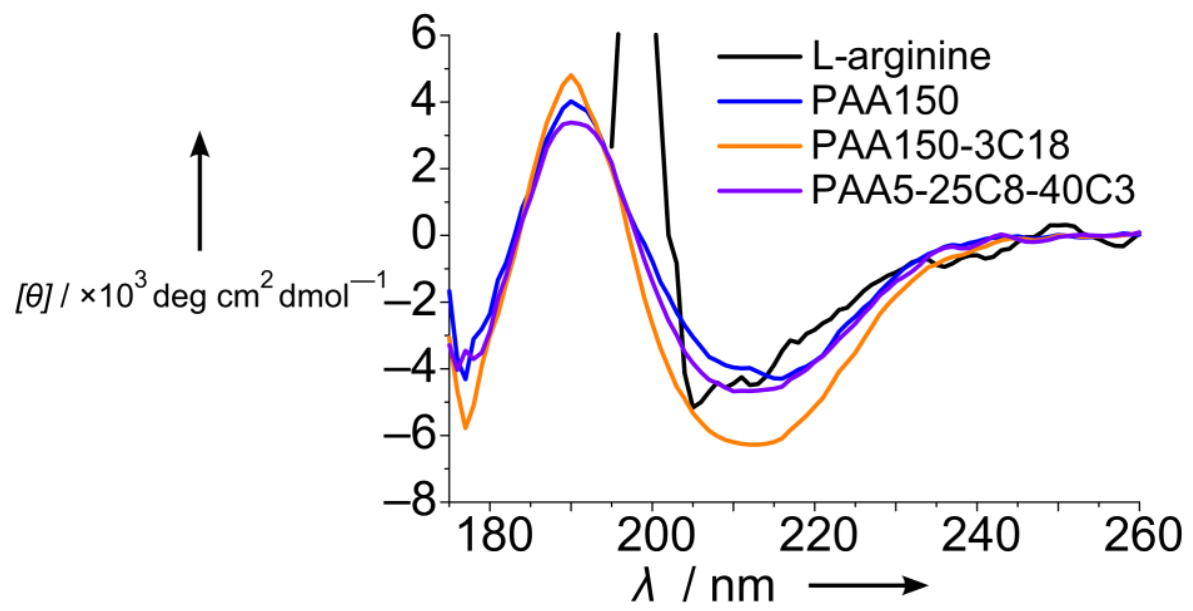

Figure 5. SRCD spectra of $\mathrm{scFv}$ Rendomab $\mathrm{B} 1$ at $25^{\circ} \mathrm{C}$ in $10 \mathrm{mM}$ Tris- $\mathrm{HCl} \mathrm{pH} 8$ after refolding with or without polymers. When refolding was performed in the absence of polymers, L-arginine $(0.4 \mathrm{M})$ was added during the renaturation protocol as described in the main text. $\mathrm{scFv}$ concentration was ca. $5 \mathrm{mg} \cdot \mathrm{mL}^{-1}$ with $1: 1 \mathrm{wt} / \mathrm{wt} \mathrm{scFv}$ :polymer ratio when polymers were added. 


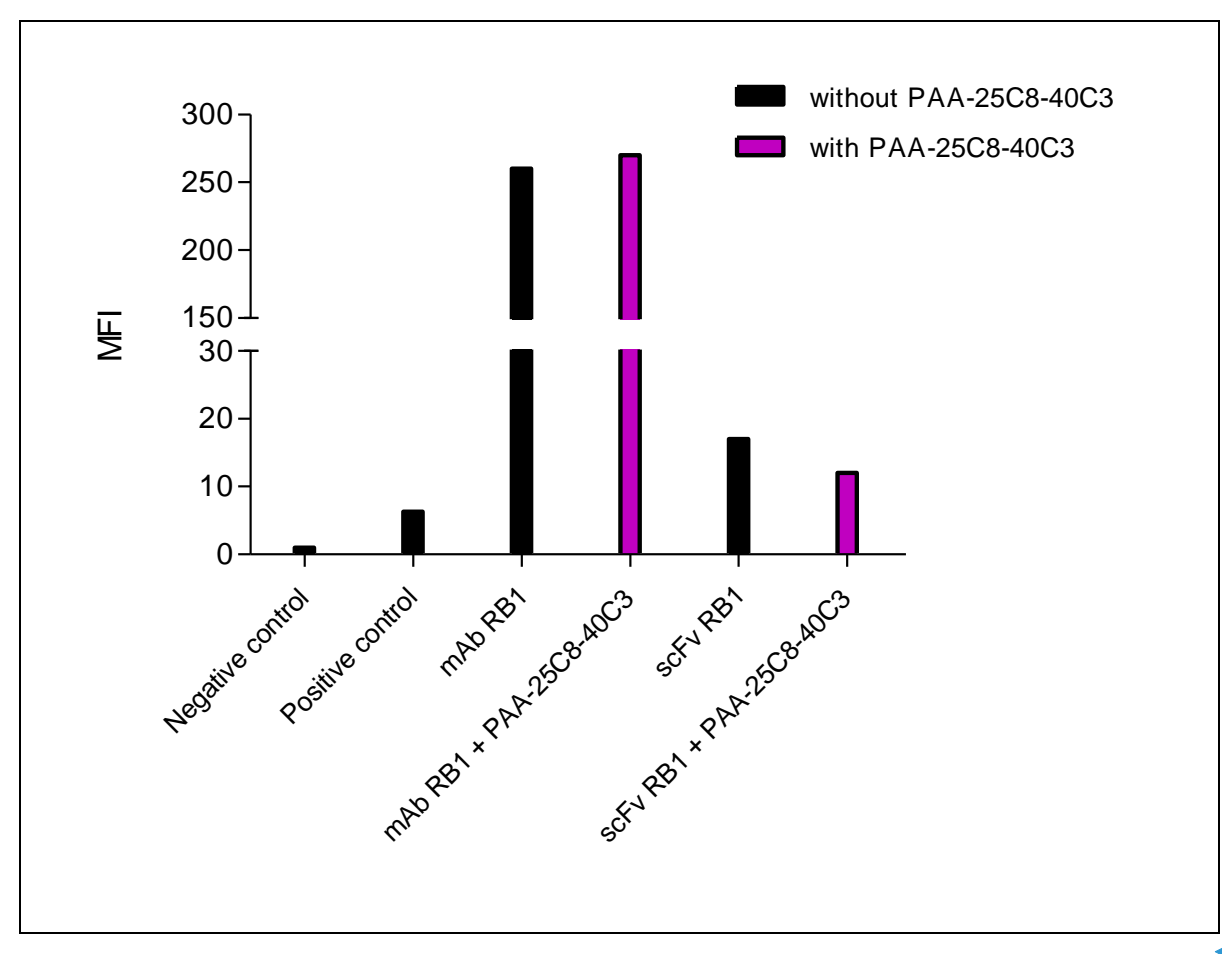

Figure 6. Index of specific binding determined from mean fluorescence intensity, MFI, as measured by flow cytometry on CHO-ETBR cell lines. MFI shown on the graph is the excess intensity after substraction of the intensity due to non specific binding measured on CHOWT. Negative control is the autofluorescence of CHO-ETBR cells (no labeling). Positive control is the MFI of cells that were revealed by binding of ET1-FAM. black bars: results for rendomab $\mathrm{B} 1 \mathrm{mAb} \mathrm{RB} 1)$ or $\mathrm{scFv}$ rendomab $\mathrm{B} 1$ ( $\mathrm{scFv} \mathrm{RB} 1)$ in the absence of polymer; purple bars:results in the presence of PAA-25C8-40C3.
Formatted: Normal, Line spacing: single

Formatted: Highlight 


\section{References.}

[1]. R.V.J. Chari, M.L. Miller, W.C. Widdison, Angewandte Chemie International Edition. 2014, 53(15), 3796-3827.

[2]. D.M. Czajkowsky, J. Hu, Z. Shao, R.J. Pleass, EMBO Mol Med. 2012, 4(10), 101528.

[3]. A.L. Nelson, MAbs. 2010, 2(1), 77-83.

[4]. P. Holliger, P.J. Hudson, Nat Biotechnol. 2005, 23(9), 1126-36.

[5]. Z.A. Ahmad, S.K. Yeap, A.M. Ali, W.Y. Ho, N.B. Alitheen, M. Hamid, Clin Dev Immunol. 2012, 2012980250.

[6]. P. Monnier, R. Vigouroux, N. Tassew, Antibodies. 2013, 2(2), 193-208.

[7]. T. Yokota, D.E. Milenic, M. Whitlow, J. Schlom, Cancer Res. 1992, 52(12), 3402-8.

[8]. A.M. Scott, J.D. Wolchok, L.J. Old, Nat Rev Cancer. 2012, 12(4), 278-87.

[9]. D. Luo, H. Li, X.-B. Tang, Biotechnology Letters. 2002, 24(6), 441-443.

[10]. N. Kobayashi, K. Odaka, T. Uehara, K. Imanaka-Yoshida, Y. Kato, H. Oyama, H. Tadokoro, H. Akizawa, S. Tanada, M. Hiroe, T. Fukumura, I. Komuro, Y. Arano, T. Yoshida, T. Irie, Analytical Chemistry. 2011, 83(23), 9123-9130.

[11]. R.-M. Lu, Y.-L. Chang, M.-S. Chen, H.-C. Wu, Biomaterials. 2011, 32(12), 32653274.

[12]. T. Dashivets, N. Wood, C. Hergersberg, J. Buchner, M. Haslbeck, Chembiochem. 2009, 10(5), 869-876.

[13]. K. Tsumoto, K. Shinoki, H. Kondo, M. Uchikawa, T. Juji, I. Kumagai, Journal of immunological methods. 1998, 219(1), 119-129.

[14]. A. Mogk, M.P. Mayer, E. Deuerling, Chembiochem. 2002, 3(9), 807-814.

[15]. M. Umetsu, K. Tsumoto, M. Hara, K. Ashish, S. Goda, T. Adschiri, I. Kumagai, Journal of Biological Chemistry. 2003, 278(11), 8979-8987.

[16]. A. Wörn, A. Plückthun, Journal of Molecular Biology. 2001, 305(5), 989-1010.

[17]. R. Glockshuber, M. Malia, I. Pfitzinger, A. Plueckthun, Biochemistry. 1990, 29(6), 1362-1367.

[18]. L. Nieba, A. Honegger, C. Krebber, A. Plückthun, Protein Engineering. 1997, 10(4), 435-444.

[19]. K. Yang, A. Basu, M. Wang, R. Chintala, M.C. Hsieh, S. Liu, J. Hua, Z. Zhang, J. Zhou, M. Li, Protein engineering. 2003, 16(10), 761-770.

[20]. A.P. Chapman, P. Antoniw, M. Spitali, S. West, S. Stephens, D.J. King, Nature biotechnology. 1999, 17(8), 780-783.

[21]. A.P. Chapman, Advanced drug delivery reviews. 2002, 54(4), 531-545.

[22]. K. Tsumoto, M. Umetsu, I. Kumagai, D. Ejima, J.S. Philo, T. Arakawa, Biotechnology progress. 2004, 20(5), 1301-1308.

[23]. T. Miyatake, S. Yoshizawa, T. Arakawa, K. Shiraki, International journal of biological macromolecules. 2016, 87563-9.

[24]. M. Kudou, D. Ejima, H. Sato, R. Yumioka, T. Arakawa, K. Tsumoto, Protein expression and purification. 2011, 77(1), 68-74.

[25]. N. Martin, D. Ma, A. Herbet, D. Boquet, F.M. Winnik, C. Tribet, Biomacromolecules. 2014, 15(8), 2952-2962.

[26]. D. Ma, N. Martin, C. Tribet, F.M. Winnik, Analytical and bioanalytical chemistry. 2014, 406(29), 7539-47.

[27]. N. Martin, J. Ruchmann, C. Tribet, Langmuir. 2015, 31(1), 338-349.

[28]. J.L. Popot, T. Althoff, D. Bagnard, J.L. Baneres, P. Bazzacco, E. Billon-Denis, L.J. Catoire, P. Champeil, D. Charvolin, M.J. Cocco, G. Cremel, T. Dahmane, L.M. de la Maza, C. Ebel, F. Gabel, F. Giusti, Y. Gohon, E. Goormaghtigh, E. Guittet, J.H. 
Kleinschmidt, W. Kuhlbrandt, C. Le Bon, K.L. Martinez, M. Picard, B. Pucci, J.N. Sachs, C. Tribet, C. van Heijenoort, F. Wien, F. Zito, M. Zoonens, Annual Review of Biophysics, Vol 40. 2011, 40379-408.

[29]. Y. Gohon, F. Giusti, C. Prata, D. Charvolin, P. Timmins, C. Ebel, C. Tribet, J.L. Popot, Langmuir. 2006, 22(3), 1281-90.

[30]. R. Borrega, C. Tribet, R. Audebert, Macromolecules. 1999, 32(23), 7798-7806.

[31]. C. Ortega, A. Herbet, S. Richard, N. Kersual, N. Costa, A. Pèlegrin, F. Ducancel, J.Y. Couraud, I. Navarro-Teulon, D. Boquet, Journal of immunological methods. 2013, 387(1), 11-20.

[32]. B. Allard, A. Wijkhuisen, A. Borrull, F. Deshayes, F. Priam, P. Lamourette, F. Ducancel, D. Boquet, J.-Y. Couraud, Mabs. 2013, 5(1), 56-69.

[33]. S. Padiolleau-Lefevre, C. Alexandrenne, F. Dkhissi, G. Clement, S. Essono, C. Blache, J.-Y. Couraud, A. Wijkhuisen, D. Boquet, Molecular Immunology. 2007, 44(8), 1888-1896.

[34]. C.T. Kuan, C.J. Wikstrand, G. Archer, R. Beers, I. Pastan, M.R. Zalutsky, D.D. Bigner, International Journal of Cancer. 2000, 88(6), 962-969.

[35]. Chrysovalanto Staneloudi, Karen A. Smith, R. Hudson, Nela Malatesti, Huguette Savoie, R.W. Boyle, J. Greenman, Immunology. 2007, 120512-517.

[36]. M. Umetsu, K. Tsumoto, M. Hara, K. Ashish, S. Goda, T. Adschiri, I. Kumagai, Journal of Biological Chemistry. 2003, 278(11), 8979-8987.

[37]. P. Sengupta, K. Garai, J. Balaji, N. Periasamy, S. Maiti, Biophys J. 2003, 84(3), 197784.

[38]. R.E. Cathou, Kulczyck.A, E. Haber, Biochemistry. 1968, 7(11), 3958-\&.

[39]. A. Micsonai, F. Wien, L. Kernya, Y.-H. Lee, Y. Goto, M. Refregiers, J. Kardos, Proceedings of the National Academy of Sciences of the United States of America. 2015, 112(24), E3095-E3103.

[40]. C.A. Orengo, A.D. Michie, S. Jones, D.T. Jones, M.B. Swindells, J.M. Thornton, Structure. 1997, 5(8), 1093-1108.

[41]. I. Roy, M.N. Gupta, Protein Engineering. 2003, 16(12), 1153-1157.

[42]. K. Mondal, S. Raghava, B. Barua, R. Varadarajan, M.N. Gupta, Langmuir. 2007, 23(1), 70-75.

[43]. P. Chanphai, L. Bekale, S. Sanyakamdhorn, D. Agudelo, H.-A. Tajmir-Riahi, Polymer. 2014, 55(2), 572-582.

[44]. S. Tomita, K. Shiraki, Journal of Polymer Science Part a-Polymer Chemistry. 2011, 49(17), 3835-3841.

[45]. D.N. Lu, Z.X. Liu, M.L. Zhang, X.G. Wang, Z. Liu, Biochemical Engineering Journal. 2006, 27(3), 336-343.

[46]. F. Cavalieri, E. Chiessi, G. Paradossi, Soft Matter. 2007, 3(6), 718-724.

[47]. X. Ge, Y.-X. Guan, J. Chen, Z. Yao, K. Cao, S.-J. Yao, Journal of Applied Polymer Science. 2009, 114(2), 1270-1277.

[48]. X. Liu, Y. Liu, Z. Zhang, F. Huang, Q. Tao, R. Ma, Y. An, L. Shi, Chemistry-a European Journal. 2013, 19(23), 7437-7442.

[49]. T. Dahmane, F. Rappaport, J.-L. Popot, European Biophysics Journal with Biophysics Letters. 2013, 42(2-3), 85-101.

[50]. Y. Nomura, M. Ikeda, N. Yamaguchi, Y. Aoyama, K. Akiyoshi, FEBS Letters. 2003, 553(3), 271-276.

[51]. J.M. Beierle, K. Yoshimatsu, B. Chou, M.A.A. Mathews, B.K. Lesel, K.J. Shea, Angewandte Chemie-International Edition. 2014, 53(35), 9275-9279.

[52]. J. Sun, J. Ruchmann, A. Pallier, L. Jullien, M. Desmadril, C. Tribet, Biomacromolecules. 2012, 13(11), 3736-3746. 
[53]. D. Rozema, S.H. Gellman, J. Am; Chem. Soc. 2005, 1172373-2374.

[54]. J.S. Mandeville, H.A. Tajmir-Riahi, Biomacromolecules. 2010, 11(2), 465-472

[55]. A. Wittemann, M. Ballauff, Macromolecular Bioscience. 2005, 5(1), 13-20.

[56]. S. Sebai, S. Cribier, A. Karimi, D. Massotte, C. Tribet, Langmuir. 2010, 26(17), 14135-14141.
Formatted: French (France)

Formatted: French (France) 